\title{
Additional pathway of transfer of uterine prostaglandin F-2 $\alpha$ to the ovary in sheep*
}

\author{
S. N. Alwachi†, K. P. Bland and N. L. Poyser $\ddagger$ \\ Department of Veterinary Physiology, Royal (Dick) School of Veterinary Studies, \\ University of Edinburgh, Edinburgh EH9 $1 Q H$, and $\ddagger$ Department of Pharmacology, \\ University of Edinburgh, Edinburgh EH8 9JZ, U.K.
}

\begin{abstract}
Summary. The concentration of prostaglandin (PG) F-2 $\alpha$ was measured in different uterine and ovarian blood vessels between Days 12 and 16 of the oestrous cycle in 14 normal ewes. Concentrations of PGF-2 $\alpha$ significantly higher than peripheral levels were found in the uterine vein $(P<0.002)$ and oviducal vein $(P<0.002)$. This suggests that an additional pathway for PGF- $2 \alpha$ transfer to the ovary exists via the venous drainage passing alongside the oviduct.
\end{abstract}

\section{Introduction}

The counter-current transfer of prostaglandin (PG) F-2 $\alpha$ from the utero-ovarian vein to the ovarian artery (Land, Baird \& Scaramuzzi, 1976) is now widely accepted as the route whereby uterine PGF- $2 \alpha$ reaches the ovaries to cause luteolysis. However, Thorburn \& Mattner (1971) failed to interrupt normal oestrous cycles in sheep when they separated the utero-ovarian vein from the ovarian artery. Furthermore, Baird \& Land (1973) found that only 4 out of 10 ewes showed persistent luteal function when the main uterine vein alone was ligated and severed. These data suggest that an additional route by which PGF- $2 \alpha$ can get from the uterus to the ovaries exists in the sheep. In the present investigation the concentrations of PGF- $2 \alpha$ in different uterine and ovarian vessels have been measured to see if such an additional pathway could be discovered.

\section{Materials and Methods}

Preparation of animals and anaesthesia

The 14 Dorset Horn $\times$ Finnish Landrace ewes used were mature and non-pregnant. They were kept in individual pens under natural daylight and fed about $1500 \mathrm{~g}$ hay daily. Oestrus was detected by daily teasing with a vasectomized ram. The first day of oestrus was taken as Day 1 of the cycle.

Anaesthesia was induced either with intravenous injection of $20 \mathrm{ml}$ alphaxalone and alphadolone acetate (Saffan: Glaxo Laboratories Ltd, Greenford, Middlesex) or with nitrous oxide and halothane, and maintained with halothane, nitrous oxide and oxygen mixture. The operations were carried out with full aseptic surgical procedures.

\footnotetext{
* Reprint requests to Dr K. P. Bland, Department of Veterinary Physiology, Royal (Dick) School of Veterinary Studies, University of Edinburgh, Edinburgh EH9 1QH. U.K.

$\uparrow$ Present address: College of Veterinary Medicine, University of Baghdad. Al-Ameria. Baghdad. Iraq.
} 


\section{Samples}

Uterine and ovarian blood samples were collected from the uterine vein and artery, oviducal vein and ovarian vein (Text-fig. 1) at laparotomy between Days 12 and 16 inclusive of 20 oestrous cycles. A peripheral blood sample from the anterior mammary vein (vena epigastrica cranialis superficialis) was also collected during most of the operations. Blood samples (approximately $3 \mathrm{ml}$ ) were taken by simple venepuncture, only from vessels on the side of the ovary containing luteal tissue. Most ewes were sampled only once but if sampled a second time a suitable interval of at least $60-90$ days was allowed to occur between samplings. Sampling was always halted if there were any signs of haematoma formation or oedema because tissue damage itself can cause prostaglandin release (Greenwood \& Kerry, 1975). Sampling therefore had to be completed within 5-10 min. Blood samples were centrifuged and stored at $-20^{\circ} \mathrm{C}$. PGF-2 $\alpha$ was extracted from plasma by the method of Blatchley \& Poyser (1974) and the onestep procedure gave $>90 \%$ recovery of PGF- $2 \alpha$. PGF- $2 \alpha$ was measured by an antibody raised in rabbits in this laboratory (Dighe, Emslie, Henderson, Rutherford \& Simon, 1975) and used the double-antibody method of separating bound from unbound labelled ligand. The antibody does not distinguish between PGF-2 $\alpha$ and PGF- $1 \alpha$ but has only low cross-reactivities $(<3.4 \%)$ with other PGs and their metabolites (Poyser \& Scott, 1980). Within-assay coefficient of variation was $12 \cdot 1 \%$ and was calculated from duplicate results obtained from each biological sample assayed. The between-assay coefficient of variation was $10 \cdot 3 \%$. The quantity incorporated into each assay for calculating this value was $160 \mathrm{pg}$ PGF- $2 \alpha$. The limit of detection of the assay, defined as the quantity of PGF- $2 \alpha$ required to cause a $10 \%$ drop in the binding of the tritiated compound when no PGF-2 $\alpha$ was present, was $40 \mathrm{pg} / \mathrm{tube}$.

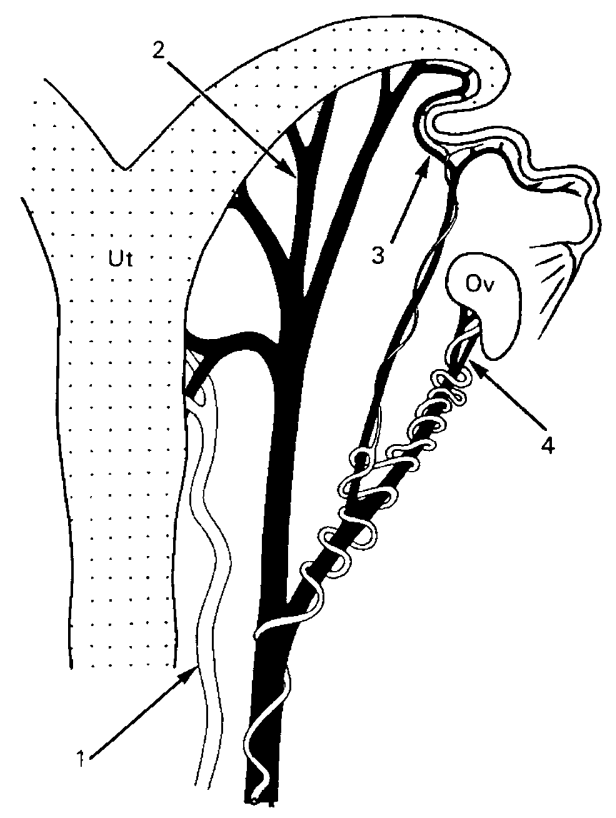

Text-fig. 1. Generalized diagram of the vasculature of the uterus (Ut) and ovary (Ov) of the ewe. Arrows indicate the approximate place from which samples were taken: uterine artery (1); uterine vein (2); oviducal vein (3); ovarian vein (4).

Progesterone concentrations were also measured in the various blood samples and the similarity of values in the oviducal vein and those in the mammary vein and uterine artery and vein suggested that there was no contamination of blood in the oviducal vein with that from the ovarian vein. 


\section{Statistical methods}

The results were analysed by Student's $t$ test for comparison of differences between two related groups.

\section{Results}

The results are shown in Table 1. All the animals had normal 16-19-day oestrous cycles during sampling. Concentrations of PGF-2 $\alpha$ varied between animals on the same day of the cycle but there was no significant difference between the mean concentrations $(\mathrm{ng} / \mathrm{ml})$ in the uterine artery $(0.68 \pm 0.16$ (s.e.m.), $n=17)$, ovarian vein $(0.80 \pm 0.18, n=14)$ and mammary vein $(0.52 \pm 0.06, n=13)$. Concentrations in the uterine vein $(2.87 \pm 0.66, n=20)$ and the oviducal vein $(1.90 \pm 0.36, n=16)$ were significantly $(P<0.002$ for both $)$ higher than the equivalent peripheral values.

Table 1. Prostaglandin F- $2 \alpha$ concentrations in various vessels in sheep on Days 12 to 16 of the oestrous cycle

\begin{tabular}{|c|c|c|c|c|c|}
\hline \multirow[b]{2}{*}{$\begin{array}{l}\text { Day of } \\
\text { cycle }\end{array}$} & \multicolumn{5}{|c|}{ PGF- $2 \alpha$ conc. $(\mathrm{ng} / \mathrm{ml})$} \\
\hline & $\begin{array}{l}\text { Mammary } \\
\text { vein }\end{array}$ & $\begin{array}{l}\text { Uterine } \\
\text { artery }\end{array}$ & $\begin{array}{l}\text { Uterine } \\
\text { vein }\end{array}$ & $\begin{array}{l}\text { Oviducal } \\
\text { vein }\end{array}$ & $\begin{array}{c}\text { Ovarian } \\
\text { vein }\end{array}$ \\
\hline $\begin{array}{r}12 * \\
*\end{array}$ & $\begin{array}{l}\left\{\begin{array}{l}0.55 \\
0.55\end{array}\right. \\
\left\{\begin{array}{l}- \\
0.62\end{array}\right. \\
0.84\end{array}$ & $\begin{array}{c}0.87 \\
1.10 \\
0.56 \\
0.30 \\
0.66 \\
-\end{array}$ & $\begin{array}{l}0.48 \\
0.98 \\
2.50 \\
2 \cdot 10 \\
0.80 \\
9.40\end{array}$ & $\begin{array}{c}0.87 \\
1.50 \\
1.60 \\
3.20 \\
3.20 \\
-\end{array}$ & $\begin{array}{l}1.30 \\
0.76 \\
2.40 \\
0.45 \\
1.03 \\
1.30\end{array}$ \\
\hline 13 & $\begin{array}{l}0.80 \\
0.36 \\
0.68 \\
0.30\end{array}$ & $\begin{array}{l}1.10 \\
0.47 \\
0.66 \\
0.80\end{array}$ & $\begin{array}{l}0.77 \\
1.59 \\
5.60 \\
1.45\end{array}$ & $\begin{array}{l}1.10 \\
0.25 \\
3.70 \\
1.21\end{array}$ & $\begin{array}{c}1.10 \\
0.30 \\
\overline{1.53}\end{array}$ \\
\hline 14 & $\begin{array}{l}- \\
-\end{array}$ & $\begin{array}{l}0.06 \\
0.62 \\
0.41 \\
0.29\end{array}$ & $\begin{array}{l}1.50 \\
5.20 \\
0.67 \\
3.22\end{array}$ & $\begin{array}{c}3.40 \\
3.50 \\
0.81 \\
-\end{array}$ & $\begin{array}{l}\overline{-} \\
\overline{0.15} \\
0.42\end{array}$ \\
\hline 15 & $\begin{array}{l}0.19 \\
0.23\end{array}$ & $\begin{array}{c}0.10 \\
-\end{array}$ & $\begin{array}{l}0.52 \\
4.29\end{array}$ & $\begin{array}{l}0.24 \\
0.60\end{array}$ & $\begin{array}{c}0.18 \\
-\end{array}$ \\
\hline 16 & $\begin{array}{l}0.20 \\
0.69 \\
- \\
0.70\end{array}$ & $\begin{array}{l}-\overline{2.80} \\
0.23 \\
0.48\end{array}$ & $\begin{array}{r}4.50 \\
10.60 \\
0.29 \\
1.02\end{array}$ & $\begin{array}{c}0.65 \\
4.60 \\
- \\
-\end{array}$ & $\begin{array}{c}0.19 \\
- \\
0.07 \\
-\end{array}$ \\
\hline
\end{tabular}

* Opposite sides of same animal.

\section{Discussion}

The elevated concentration of PGF-2 $\alpha$ in the oviducal vein must have been of uterine or oviducal origin because the PGF- $2 \alpha$ concentration in the ovarian vein was not elevated. The variation between animals was probably due to the episodic nature of the release of this substance from the uterus (Thorburn, Cox, Currie, Restall \& Schneider, 1973).

These results suggest that PGF- $2 \alpha$ can also reach the ovary via the venous drainage passing alongside the oviduct. This oviducal vein is usually involved in the vascular plexus in the 
ovarian pedicle (see Text-fig. 1) and frequently anastomoses with the ovarian vein which is a major constituent of this plexus (Del Campo \& Ginther, 1973). McCracken \& Einer-Jensen (1976) suggested that the vascular plexus in the ovarian pedicle may form a counter-current transfer system whereby ovarian steroids could feedback and regulate further ovarian steroid production. Such a feedback system was claimed by Walsh, Yutrzenka \& Davis (1979), although Caffrey, Nett, Abel \& Niswender (1979) were unable to confirm its existence. The present data suggest that this vascular plexus in the ovarian pedicle may be involved in the transfer of PGF-2 $\alpha$ from the oviducal and ovarian veins into the ovarian artery. In the ewes which returned to heat in the study of Baird \& Land (1973), the tubal branches of the uterine vein had formed anastomoses between the uterine and ovarian veins; division of these anastomotic veins in addition to the main uterine vein inhibited luteal regression in 6 out of 7 ewes. The utero-ovarian vascular system in sheep is dynamic and readily compensates for intervention. In view of this Ginther (1974) suggested that the relative amount of uterine venous effluent which discharged through the oviducal veins must be small in normal ewes, but could be considerable after ligation of the main uterine vein. However, even in normal animals the importance of the oviducal veins may vary; in the present study the oviducal veins in some of the animals were large and prominent while in others they were very small.

We thank Mrs P. Forbes for excellent technical assistance; $\mathrm{Mr}$ T. Frankland and $\mathrm{Mr} \mathrm{M}$. Camburn for assistance with anaesthesia; Miss A. Pelanis, Miss L. Gilchrist and Miss S. North for the radioimmunoassays; and the Centre for Laboratory Animals, University of Edinburgh, for animal accommodation and assistance. The work was supported by grants from the Agricultural Research Council to K.P.B. (AG.15/114), a Medical Research Council programme grant to Professor E. W. Horton and a scholarship to S.N.A. from the Ministry of Higher Education and Scientific Research, Baghdad, Iraq.

\section{References}

Baird, D.T. \& Land, R.B. (1973) Division of the uterine vein and the function of the adjacent ovary in the ewe. J. Reprod. Fert. 33, 393-397.

Blatchley, F.R. \& Poyser, N.L. (1974) The effect of oestrogen and progesterone on the release of prostaglandins from the uterus of the ovariectomized guinea-pig. J. Reprod. Fert. 40, 205-209.

Caffrey, J.L., Nett, T.M., Abel, J.H. \& Niswender, G.D. (1979) Activity of $3 \alpha$-hydroxy- $\Delta^{5}$-steroid dehydrogenase $/ \Delta^{5}-\Delta^{4}$-isomerase in the ovine corpus luteum. Biol. Reprod. 20, 279-287.

Del Campo, C.H. \& Ginther, O.J. (1973) Vascular anatomy of the uterus and ovaries and the unilateral luteolytic effect of the uterus: angioarchitecture in sheep. Am. J. vet. Res. 34, 1377-1385.

Dighe, K.K., Emslie, H.A., Henderson, L.K., Rutherford, F. \& Simon, L. (1975) The development of antisera to prostaglandin $E_{2}$ and $F_{2 \alpha}$ and their analysis using solid-phase and double antibody radioimmunoassay methods. Br. J. Pharmac. 55, 503-514.

Ginther, O.J. (1974) Internal regulation of physiological processes through local veno-arterial pathways: a review. J. Anim. Sci. 39, 550-564.

Greenwood, B. \& Kerry, P.J. (1975) Prostaglandin production by a mild inflammatory lesion in sheep. Br.J. Pharmac. 53, 305-307.
Land, R.B., Baird, D.T. \& Scaramuzzi, R.J. (1976) Dynamic studies of prostaglandin $F_{2 \alpha}$ in the uteroovarian circulation of the sheep. J. Reprod. Fert. 47, 209-214.

McCracken, J.A. \& Einer-Jensen, N. (1976) The counter-current transfer of progesterone in the ovarian vascular pedicle. Proc. 5th Int. Congr. Endocrinology, Hamburg, Abstr. 775, p. 320.

Poyser, N.L. \& Scott, F.M. (1980) Prostaglandin and thromboxane production by the rat uterus and ovary in vitro during the oestrous cycle. J. Reprod. Fert. $60,33-40$.

Thorburn, G.D. \& Mattner, P.E. (1971) Anastomosis of the utero-ovarian and anterior mammary veins for collection of utero-ovarian venous blood: progesterone secretion rates in cyclic ewes. J. Endocr. 50, 307-320.

Thorburn, G.D., Cox, R.I., Currie, W.B., Restall, B.J. \& Schneider, W. (1973) Prostaglandin F and progesterone concentrations in the utero-ovarian venous plasma of the ewe during the oestrous cycle and early pregnancy. J. Reprod. Fert., Suppl. 18, 151-158.

Walsh, S.W., Yutrzenka, G.J. \& Davis, J.S. (1979) Local steroid concentrating mechanism in the reproductive vasculature of the ewe. Biol. Reprod. 20, $1167-1171$. 